\title{
University of Groningen
}

\section{Geographical differences in heart failure characteristics and treatment across Europe}

Lombardi, Carlo Mario; Ferreira, Joao Pedro; Carubelli, Valentina; Anker, Stefan D.; Cleland, John G.; Dickstein, Kenneth; Filippatos, Gerasimos; Lang, Chim C.; Ng, Leong L.; Ponikowski, Piotr

Published in:

Clinical Research in Cardiology

DOI:

10.1007/s00392-019-01588-7

IMPORTANT NOTE: You are advised to consult the publisher's version (publisher's PDF) if you wish to cite from it. Please check the document version below.

Document Version

Final author's version (accepted by publisher, after peer review)

Publication date:

2020

Link to publication in University of Groningen/UMCG research database

Citation for published version (APA):

Lombardi, C. M., Ferreira, J. P., Carubelli, V., Anker, S. D., Cleland, J. G., Dickstein, K., Filippatos, G., Lang, C. C., Ng, L. L., Ponikowski, P., Samani, N. J., van Veldhuisen, D. J., Zannad, F., Voors, A., \& Metra, M. (2020). Geographical differences in heart failure characteristics and treatment across Europe: results from the BIOSTAT-CHF study. Clinical Research in Cardiology, 109(8), 967-977. https://doi.org/10.1007/s00392-019-01588-7

\section{Copyright}

Other than for strictly personal use, it is not permitted to download or to forward/distribute the text or part of it without the consent of the author(s) and/or copyright holder(s), unless the work is under an open content license (like Creative Commons).

The publication may also be distributed here under the terms of Article $25 f a$ of the Dutch Copyright Act, indicated by the "Taverne" license. More information can be found on the University of Groningen website: https://www.rug.nl/library/open-access/self-archiving-pure/taverneamendment. 


\section{Geographical differences in heart failure characteristics and treatment across Europe: results from the BIOSTAT-CHF study}

Carlo Lombardi, $\mathrm{MD}^{1}$ João Pedro Ferreira, MD, $\mathrm{PhD}^{2}$; Valentina Carubelli, $\mathrm{MD}^{1}$; Stefan D. Anker, $\mathrm{MD}, \mathrm{PhD}^{3}$; John G. Cleland, MD, $\mathrm{PhD}^{4}$; Kenneth Dickstein, $\mathrm{MD}, \mathrm{PhD}^{5,6}$; Gerasimos Filippatos, MD, $\mathrm{PhD}^{7}$; Chim C. Lang, $\mathrm{MD}^{8}$; Leong Ng, $\mathrm{MD}^{9}$; Piotr Ponikowski, MD, $\mathrm{PhD}^{10}$; Nilesh J. Samani, MD, $\mathrm{PhD}^{11}$; Dirk J. van Veldhuisen, MD; PhD ${ }^{12}$; Faiez Zannad, MD, $\mathrm{PhD}^{2}$; Adriaan Voors, MD, $\mathrm{PhD}^{12}$; Marco Metra, MD ${ }^{1}$

\section{Affiliations:}

${ }^{1}$ Cardiology, Department of Medical and Surgical Specialties, radiological Sciences and Public Health. University of Brescia. Italy

${ }^{2}$ INSERM, Centre d'Investigations Cliniques Plurithématique 1433, Université de Lorraine, CHRU de Nancy and F-CRIN INI-CRCT, Nancy, France.

${ }^{3}$ Department of Innovative Clinical Trials, University Medical Centre Göttingen (UMG), Robert-Koch-Straße, D-37075, Göttingen, Germany.

${ }^{4}$ Robertson Centre for Biostatistics and Glasgow Clinical Trials Unit, Glasgow, UK.

${ }^{5}$ University of Bergen, Bergen, Norway.

${ }^{6}$ Stavanger University Hospital, Stavanger, Norway.

${ }^{7}$ National and Kopodistrian University of Athens, School of Medicine, Heart Failure Unit, Department of Cardiology, Athens University Hospital Attikon, Rimini 1, Athens 12462, Greece.

${ }^{8}$ Division of Molecular and Clinical Medicine, Ninewells Hospital and Medical School, University of Dundee, Dundee, UK.

${ }^{9}$ Department of Cardiovascular Sciences, University of Leicester, Leicester, United Kingdom; NIHR Leicester Cardiovascular Biomedical Research Unit, Glenfield Hospital, Leicester, United Kingdom

${ }^{10}$ Department of Cardiology, Centre for Heart Diseases, 4th Military Hospital, Wroclaw, Poland; Department of Heart Diseases, Wroclaw Medical University, Wroclaw, Poland.

${ }^{11}$ De partment of Cardiovascular Sciences, University of Leicester, BHF Cardiovascular Research Centre, Gl enfield Hospital, Groby Rd, Leicester, LE3 9QP, United Kingdom

${ }^{12}$ Department of Cardiology, University of Groningen, University Medical Center Groningen, Hanzeplein 1, 9713 GZ Groningen, The Netherlands. 
Short running title: Geographical differences in the BIOSTAT-CHF study

Word count: 4137

Key words: heart failure; geographical variations; geographical differences; income; outcomes; BIOSTAT-CHF

\section{Corresponding author}

Marco Metra, MD. Division of Cardiology, Department of Medical and Surgical Specialties, Radiological Sciences, and Public Health, University and Civil Hospital of Brescia, Brescia, Italy. 


\section{Abstract (187 words)}

Background: Geographical differences may impact treatment of heart failure (HF) and the results of clinical trials. We have investigated differences between geographical areas across Europe in the BIOSTAT-CHF program.

Methods: Patients with worsening HF enrolled in BIOSTAT-CHF were subdivided, according to the European geographical areas, into those from Northern countries (NC, Netherlands, Norway, Sweden, United Kingdom), Central countries (CC, Germany, Poland, Serbia, Slovenia), and Mediterranean countries (MC, France, Greece, Italy). Patients were compared for baseline characteristics, treatment, and outcomes. The primary endpoint was a composite of all-cause mortality or HF hospitalization.

Results: Among 2516 patients enrolled in BIOSTAT-CHF, 814 (32.3\%) were from (NC), 816 (32.4\%) from CC, and 886 (35.2\%) from MC. Patients from NC were older, had more severe signs and symptoms of HF and non-cardiac comorbidities, compared to those from CC and MCl. The primary endpoint occurred at a higher rate in NC (44.3\% versus $37.4 \%$ in CC and $39.6 \%$ in $M C ; p=0.014)$ but this difference became non significant after adjustment for baseline variables.

Conclusion: Several differences in patients ' profile and treatment were identified across Europe in BIOSTAT-CHF and they accounted for differences in outcomes.

Key-words: geographical differences; heart failure; treatment up-titration. 


\section{Introduction}

Heart failure (HF) has a worldwide diffusion and its prevalence is increasing due to the aging of the population and the efficacy of treatment of acute cardiovascular diseases ${ }^{1,2,3,4}$ Geographical differences may have an impact on clinical characteristics and treatment of the patients with HF and influence the results of clinical trials..$^{5,6,7,8,9}$ These differences may be important even within one single continent, such is the case of European countries. ${ }^{10,11,12,13}$ This was first shown in retrospective analyses of randomized trials and then in registries.$^{14,15,16}$ The European Society of Cardiology (ESC) HF Pilot Survey showed differences across European geographical areas. ${ }^{15}$ Patients from Eastern European countries were younger, with a more frequent ischemic etiology and had higher systolic blood pressure. Patients in Northern countries had a lower left ventricular ejection fraction (EF). Devices were underused in Eastern countries. ${ }^{15}$ In the more recent ESC-HF Long-term registry, patients from middle Eastern and Northern European countries were older and more likely to have an ischemic eti ology. The use of implantable cardioverter defibrillators (ICDs) or cardiac resynchronization therapy with defibrillation (CRT-D) was also different across European areas. Geographical areas were independently related with outcomes of chronic heart failure patients at multivariable analysis, with a lower risk of events in Northern European versus Southern European countries. ${ }^{16,17}$

The BIOlogy Study to Tailored Treatment in Chronic HF (BIOSTAT-CHF) is a European multicenter, prospective study which included patients with worsening signs and/or symptoms of HF who were considered to be on suboptimal medical treatment. ${ }^{18}$ Patients were enrolled from 11 European countries. This study therefore allows the assessment of geographical differences between different areas of Europe with respect of a peculiar study population, that is to say patients with worsening HF followed by mostly tertiary referral centers. The aim of this secondary, nonprespecified, analysis is to investigate the geographic differences in the clinical' characteristics, 
prognosis, and treatment between the patients enrolled from different geographical areas in BIOSTAT-CHF.

\section{Methods}

The design and main results of the study is described in detail elsewhere. ${ }^{18}$ In summary el igibility criteria at screening included signs and symptoms of new-onset or worsening $\mathrm{HF}$, cardiac dysfunction shown by a left ventricular $E F \leq 40 \%$ or brain natriuretic peptide (BNP) $>400 \mathrm{pg} / \mathrm{mL}$ or $\mathrm{N}$-terminal pro-brain natriuretic peptide (NT-proBNP) $>2000 \mathrm{pg} / \mathrm{mL}$, treatment with oral or intravenous furosemide or equivalent $\geq 40 \mathrm{mg}$ daily. Patients had to be not previously treated with angiotensin-converting enzyme (ACE) inhibitors or angiotensin receptor antagonists (ARBs) and beta-blockers or should have been receiving $\leq 50 \%$ of their target doses according to current guidelines. ${ }^{19}$

Patients hospitalized for acute HF and outpatients with of signs and symptoms of HF could be included in the study. The primary endpoint was time to a composite of all-cause death and heart failure hospitalization. The trial was approved by the ethics committee at each study center. All the patients provided written informed consent. The study design included a 3-month uptitration phase, during which the investigators had to introduce and/or uptitrate guidel ines -recommended medications with special attention to ACE-inhibitors, ARBs, beta-blockers and mineralocorticoid receptor antagonists (MRA). The NT-proBNP values were measured using the Proseek Multiplex are CVDIII panel (Olink Proteomics AB, Uppsala, Sweden) and presented in normalized protein expression (NPX) values, which is an arbitrary unit on a log2 scale in which a high value corresponds to a higher protein expression. ${ }^{20}$
Opmer king [VA(3]: Please add: Development and validation of multiv ariable models to predict mortality and hospitalization in patients with heart failure. Voors AA, Ouwerkerk W, Zanna $\mathrm{F}$, van Veldhuisen DJ, Samani N. Ponikowski P, Ng LL, Metra M, T Maaten JM, Lang CC, Hillege HL van der Harst $P$, Filippatos $G$, Dickstein K, Cleland JG, Anker S Zwinderman $\mathrm{AH}$

Eur J Heart Fail. 2017 May;19(5):627-634.

Determinants and clinical outcom of uptitration of ACE-inhibitors ar beta-blockers in patients with hea failure: a prospective European study.

Ouwerkerk W, Voors AA, Anke SD, Cleland JG, Dickstein K, Filippatos G, van der Harst P, Hillege HL, Lang CC, Ter Maate JM, Ng LL, Ponikowski P, Samar NJ, van Veldhuisen DJ, Zannad Metra $\mathrm{M}$, Zwinderman $\mathrm{AH}$.

Eur Heart J. 2017 Jun

21;38(24):1883-1890. Mineralocorticoid receptor

antagonist pattern of use in hear failure with reduced ejection f raction: findings from $\mathrm{BIOSTAT}$ CHF

Ferreira JP, Rossignol P, Machu JL, Sharma A, Girerd N, Anker S

Cleland JG, Dickstein K, Filippat

G, Hillege HL, Lang CC, Ter Maaten JM, Metra M, Ng L,

Ponikowski P, Samani NJ, van

Veldhuisen DJ, Zwinderman $\mathrm{AH}$ Voors A, Zannad F.

Eur J Heart Fail. 2017 Oct;19(10):1284-1293. 
For the purpose of this analysis, the study patients of BIOSTAT-CHF were subdivided according to their country of origin geographical areas. Northern countries included Netherlands, Norway, Sweden, and United Kingdom; Central countries included Germany, Poland, Serbia, and Slovenia; Mediterranean countries included France, Greece, and Italy.

\section{Statistical Analysis}

Conti nuous variables are shown as mean \pm standard deviation, dichotomous variables as number

(\%). Comparisons of demographic and clinical baseline characteristics, medical history, and medications were evaluated by ANOVA for continuous variables and the 2 test for categorical variables. Categorical variables are expressed as frequencies and proportions (\%). Individual country contribute to enrollment and treatment according to geographic area are expressed as frequencies and proportions (\%). Kaplan Meier plots were generated by each area to evaluate clinical outcomes. A p value $<0.05$ was used to indicate statistical significance. The outcomes of interest are time to a composite of death or unscheduled hospitalizations for heart failure, HF hospitalization, and all-cause mortality. Cox proportional hazard regression models were used to model long-term event rate both in univariable and multivariable analysis. A validated mul tivariable risk model was used to predict all-cause mortality and hospitalizations and assess the independent prognostic value of geographical areas. ${ }^{21}$ Cox model's assumptions has been verified. Statistical analysis was performed with Stata ${ }^{\circledR}$ Software 14.2 (Release 14, 2015, StataCorp LP, College Station, Texas), was used for the main analysis .

\section{Results}


Patients were enrolled from December 2010 to December $15^{\text {th }} 2012$. The end of study follow-up was on April $1^{\text {st }}$ 2015. A total of 2516 patients were enrolled in the BIOSTAT-CHF study with a median follow-up of 21 months (interquartile range, 15-27months). The distribution according to the geographic region was as follows: 814 (32.3\%) in Northern countries, 816 (32.4\%) in Central countries, and $886(35.2 \%)$ in Mediterranean countries. Results regarding baseline characteristics of the patients subdivided according to the European area are shown in Table $\mathbf{1}$ and individual country contribute to enrollment in the study is represented in figure 1. Data about enrollment contribute and baseline characteristics for each individual country are listed in Table 2.

\section{Baseline characteristics}

Patients from Northern European countries were older, more often female, had higher heart rate (88.3 \pm 24.7 beats per minute in Northern area vs $79.6 \pm 19.5$ Central area and $79.3 \pm 18.4$ in the Mediterranean area; $\mathrm{p}<0.001)$, more severe signs and symptoms of HF and higher NT pro BNP values $(3.40 \pm 1.34 \mathrm{pg} / \mathrm{mL}$ in the Northern area vs $2.79 \pm 1.39 \mathrm{pg} / \mathrm{mL}$ in the Central area vs $2.89 \pm 1.36$ $\mathrm{pg} / \mathrm{mL}$ in the Mediterranean area; $\mathrm{p}<0.001)$. Glomerular filtration rate was lower in Norther area patients compared with others (eGFR, $\mathrm{ml} / \mathrm{min} / 1.73 \mathrm{~m} 2$, NC 58.9 \pm 23.0, CC $66.3 \pm 22.4$, $m c 62.2 \pm 23.6, p<0.001)$.

Figure 4 represents the country-by-country distribution of signs of congestion. Patients from the Northern European countries tended to have a higher prevalence of pulmonary congestion, peripheral edema and el evated jugular venus pressure.

Patients from Central Europe were the younger (66.1 \pm 10.7 years, $p>0.001)$, with a numerical higher prevalence of ischemic etiology of HF (46.7\% versus $39.9 \%$ in Northern countries versus 45.7\% in Mediterranean countries) and with higher prevalence of hypertension ( $p=0.038)$, whereas the proportion of patients with atrial fibrillation was numerically lower compared with 
other areas (41.8\% versus 47.5 Northern area versus $46.8 \%$ Mediterranean area Table 1 ). The use of implantable devices were most common in Mediterranean countries as well a previous history of coronary revascularization with percutaneous coronary angioplasty $(\mathrm{PCl})$ or coronary artery by pass (BPAC).

\section{Treatment}

Data regarding treatments are shown in Table 1 and Figure 2 and refer to the end of the 3-months uptitration period. The prescription of guidelines-recommended therapies varied widely across groups. Patients from Central Europe received more ACE-inhibitors or ARBs compared to those from Northern European and Mediterranean countries (78.4\% versus $73.3 \%$ and $63.6 \%$, respectively). Even beta-blockers and MRA were administered more often in central Europe compared with the other countries $(87.5 \%$ versus $81.3 \%$ and $80 \%$ for beta-blockers and $66.5 \%$ versus $42.6 \%$ and $50.7 \%$ in Northern European and Mediterranean countries, respectively).

Digoxin was still frequently prescribed in Central Europe (23.5\%) and was relatively uncommon in Mediterranean patients (14.6\%). Loop diuretics were prescribed in almost all patients, with slightly lower, but statistically significant $(p=0.026)$, rates in Mediterranean countries (99.1\% versus $99.5 \%$ and $100 \%$ in the Northern and Central countries, respectively).

Notably, the proportion of patients receiving $\geq 50 \%$ of the target dose of both ACE-I/ARB after|the uptitration phase was higher in the Northern countries compared with the other regions (60\%, versus $58.7 \%$ in the Central countries and $46.5 \%$ in the Mediterranean ones; $p$ 0.001). Similarly, achievement of $\geq 50 \%$ of the target doses of beta-blockers was greater in patients in the

Opmerking [VA(6]: Please note th this was required by the protocol!

Opmer king [c7]: Dr.Woors: First, was afraid about duplicate data on uptitration of therapy, since it was already described in the paper by Wouter that you had attached.

However, strictly speaking, we did report on the differences on medication use and uptitration in th three regions. So, we cannot be blames by publishing duplicate findings. We might suggest to still have this in the paper, albeit not to much pronounced. What do you think?

Dr.Metra: Yes. We show the data for the 3 groups and we take ca if this in the discussion

briefly include in the results also in the discussion the data uptitr ation of ther apy in the 3 regions 
Northern countries than in the Central and Mediterranean ones $(46.6 \%, 32.5 \%, 31.2 \%$, respectively, $\mathrm{p}<0.001)$.

\section{Outcomes and interaction with treatment}

The incidence of the endpoints and the prognostic models are shown in Table 1 Patients from Central countries had the numerical lower rate of the primary endpoint of the study of all-cause mortality and HF hospitalization (44.3\% in the Northern countries versus $37.4 \%$ in the Central countries and $39.6 \%$ in the Mediterranean ones; $p=0.014)$. A similar result was found for all-cause mortality $(29.2 \%, 24.1 \%$ and $25.1 \%$ in the Northern, Central and Mediterranean countries, respectively; $p=0.043)$ and $\mathrm{HF}$ hospitalizations alone $(27.1 \%, 21.0 \%$ and $24.5 \%$ in the Northern, Central and Mediterranean countries, respectively; $p=0.014)$. During the uptitration period patients from Northern Europe had a significant increase in all-cause mortality compared with other regions (NC 8.2\%, CC 5.3\%, MC 4.6\%, p 0.004). Figure 5 represents the country-by-country distribution of outcomes.

Unadjusted and adjusted outcome analyses for the primary and secondary endpoints are shown at Table 3. After adjustment for other predictors of outcome, there were no significant differences between geographical areas in term of relative risk of clinical outcomes. Differences in the outcomes were evaluated by the Log-rank test and are shown in the Kaplan-Meier curves (figure $3 A, 3 B, 3 C)$.

\section{Discussion}


This analysis of BIOSTAT-CHF shows that there are marked differences in patient characteristics and HF treatment in different geographical areas in Europe. Patients from Northern Europe were older, more often female and had higher heart rate, more severe signs and symptoms of HF and higher NT-proBNP values. Patients from Central Europe were younger, had a higher prevalence of hypertension and were more likely to receive ACE-inhibitor/ARBs, beta-blockers and MRAs at bas eline. Mediterranean patients were more likely to be diabetics and had a greater history of PCA or CABG. A device implantation was more likely in these patients. In general, patients from Northern and Central Europe had a greater severity of heart failure (figure 4). These characteristics accounted for their worse outcomes so that differences in outcomes became not significant after adjustment at multivariable analysis.

In a previous analysis of BIOSTAT-CHF study reaching less of $50 \%$ of the recommended doses of ACE inhibitors/ARBs and beta-blockers was associated with a greater risk of death and/or heart failure hospitalization. The authors also demonstrated that achieving $\geq 50 \%$ of the target doses of these drugs predicted better outcomes and this association persisted after adjustment for baseline variables. ${ }^{2120,22}$ In our analisys patients from Nothern Europe have reached higher doses of Ace-inhibitors/ARBs and beta-blockers compared with other regions. Patients from this region also showed at univariate anlysis higher mortality rates during the titration period compared with Central and Mediterranean patients (table 1). (Al though) patients from Northern Europe were the ol dest, the presence of common co-mobidities usually related with age such as diabetes, arterial hypertension and chronic kidney desease were lower than in Central Europe and in the Mediterranean area. This data are also consitent with the Heart Failure Long-Term Registry (ESCHF-LT) in which the proportion of patients with diabetes and hypertension in both acute and chronic HF were higher in the Northen Europe compared with other european countries. 
In general our results confirm previous studies showing significant differences in the characteristics, outcomes and medical treatment of patients with HF from different geographical areas. ${ }^{5-14}$ Many factors may account for these differences within one continent and may include climate, socioeconomic conditions, income, health system organization. The organization of the heal th care system seems particularly important and may account for the greater severity of the patients followed in Northern European countries. ${ }^{23}$ An intensive nurse-coordinated postdischarge program including nurse training to early recognize signs and symptoms of HF and tel ephone calls has been shown to improve outcomes, compared with standard usual care. ${ }^{24}$ Non-pharmacological treatment of HF also differed across regions. Patients from the Central countries were less likely to receive ICD and CRT-D devices (compared with?) as well as coronary revascularization despite their higher proportion of coronary artery disease. Socioeconomic factors are well known determinants of the use of devices and may have had a major role also in our patients. ${ }^{22}$

National income is another determinant of the quality of health care offered by a nation. Indeed, high income European countries provide citizens a better quality of care especially for what concerns disease-management specific programs as well as integrated prevention initiatives often realized with the help of dedicated medical and nurse-led programs. ${ }^{25}$ The Prospective Urban Rural Epidemiologic (PURE) study has shown that the rates of major cardiovascular disease and death were higher in low-income countries than in high-income countries despite having a higher burden of cardiovascular risk factors. ${ }^{26}$ The PURE study evaluated 628 urban and rural communities in 17 countries from Asia, Africa, North and South America and Europe.

Our results show the same events rates in patients coming from different countries, independently from their incomes. This may be caused by lower differences in the healthcare systems, above all when related to tertiary care centers, such as those involved in BIOSTAT-CHF, 
compared to a worldwide study such as PURE. Income should, however, be considered as a potential novel variable on HF outcomes in the contest of international mega trials. ${ }^{27,28}$ In our study, variables related to HF severity were the only determinants of outcomes at multivariable analysis. Medical treatment, despite significant geographical differences, had no independent role. This is likely caused by the importance of guidelines application in our study.

\section{Limitations}

One major limitation is the representativeness of our patients. BIOSTAT-CHF involved only 11 countries, so that a large number of European countries were not included. Even more important, only a few centers were included in each country and these were mainly tertiary care centers. The value of this analysis is more in showing how differences in clinical characteristics and medical prescriptions can lose their impact on outcomes once treatment is optimized in all the patients. The subdivision of countries was based on geographical criteria. However, this may not reflect real differences between different areas. For instance, the Mediterranean area was slightly penalized as represented only by two countries (Italy and Greece) with a strong Mediterranean vocation and by France, which has many social and economic aspects more closely related to the European Central countries. Differences in the health care systems, delivery of care and incomes are present between different geographical areas and they were likely the main determinants of our results. However, unfortunately these variables were not collected in BIOSTAT-CHF. Di etary aspects, such as salt content, may also have had a role. ${ }^{26}$

However, all the countries in this study where broadly distributed across European territory and well represented each macro area. However, some sites have contributed to enrollment for a preponderant portion of patients for their respective country, and therefore a "single-center" driven effect cannot be excluded (supplementary table 1). 


\section{Conclusion}

Several differences in patients ' profile, treatment, and outcomes across Europe were identified in the BIOSTAT-CHF study. Despite the different clinical characteristics linked to the geographical area there were no differences in their outcomes after adjustment for baseline characteristics and treatment. Country incomes and healthcare organization might explain most of these differences. 


\section{Table legend}

Table 1: baseline characteristics of the patients subdivided according to the European area

\begin{tabular}{|c|c|c|c|c|}
\hline Variables & Northern Area & Central Area & Mediterranean Area & $p$ value for trend \\
\hline Number (\%) & $814(32.3)$ & $816(32.4)$ & $886(35.2)$ & $<0.001$ \\
\hline Age,y & $70.7 \pm 11.9$ & $66.1 \pm 10.7$ & $68.4 \pm 12.6$ & $<0.001$ \\
\hline Male sex, n (\%) & $548(67.3)$ & $624(76.5)$ & $674(76.1)$ & $<0.001$ \\
\hline Race, n (\%) & & & & 0.057 \\
\hline White Caucasian & $802(98.5)$ & $813(99.6)$ & $874(98.6)$ & \\
\hline Other & $12(1.5)$ & $3(0.4)$ & $12(1.4)$ & \\
\hline $\mathrm{BMI}, \mathrm{Kg} / \mathrm{m2}$ & $27.7 \pm 5.9$ & $28.3 \pm 5.1$ & $27.6 \pm 5.4$ & 0.021 \\
\hline HR, bpm & $88.3 \pm 24.7$ & $79.6 \pm 19.5$ & $79.3 \pm 18.4$ & $<0.001$ \\
\hline $\mathrm{SBP}, \mathrm{mmHg}$ & $125.3 \pm 24.8$ & $126.4 \pm 19.8$ & $122.6 \pm 20.7$ & 0.001 \\
\hline Pulmonary rales, n (\%) & $434(57.0)$ & $364(44.9)$ & $493(56.5)$ & $<0.001$ \\
\hline Peripheral edema, $\mathbf{n}(\%)$ & $455(65.8)$ & $415(55.2)$ & $386(58.9)$ & $<0.001$ \\
\hline Elevated JVP, n (\%) & $249(40.8)$ & $128(20.6)$ & $177(34.0)$ & $<0.001$ \\
\hline NYHA class III/IV, n (\%) & $506(66.7)$ & $492(60.3)$ & $524(60.2)$ & 0.010 \\
\hline Orthopnea, n (\%) & $370(45.6)$ & $238(29.2)$ & $271(30.6)$ & $<0.001$ \\
\hline LVEF, $\%$ & $31.6 \pm 11.9$ & $30.7 \pm 10.8$ & $30.8 \pm 9.3$ & 0.280 \\
\hline $\begin{array}{l}\text { Primary HF etiology, } \mathrm{n}(\%) \\
\text { Ischemic }\end{array}$ & $317(38.9)$ & $381(46.7)$ & $405(45.7)$ & 0.006 \\
\hline Hypertensive & $79(9.7)$ & $89(10.9)$ & $86(9.7)$ & \\
\hline Valvular & $72(8.8)$ & $63(7.7)$ & $55(6.2)$ & \\
\hline Other/miscellaneous & $346(42.5)$ & $283(34.7)$ & $340(38.4)$ & \\
\hline Hemoglobin, g/dL & $13.0 \pm 2.0$ & $13.5 \pm 1.8$ & $13.0 \pm 1.8$ & $<0.001$ \\
\hline eGFR, $\mathrm{ml} / \mathrm{min} / 1.73 \mathrm{~m}^{2}$ & $58.9 \pm 23.0$ & $66.3 \pm 22.4$ & $62.2 \pm 23.6$ & $<0.001$ \\
\hline Sodium, $\mathrm{mmol} / \mathrm{L}$ & $138.9 \pm 4.0$ & $139.8 \pm 3.8$ & $138.8 \pm 4.1$ & $<0.001$ \\
\hline Potassium, $\mathrm{mmol} / \mathrm{L}$ & $4.2 \pm 0.5$ & $4.4 \pm 0.6$ & $4.2 \pm 0.6$ & $<0.001$ \\
\hline LogNt-proBNP, ng/L & $3.40 \pm 1.34$ & $2.79 \pm 1.39$ & $2.89 \pm 1.36$ & $<0.001$ \\
\hline Hypertension, $\mathrm{n}(\%)$ & $410(50.4)$ & $615(75.4)$ & $544(61.4)$ & $<0.001$ \\
\hline Atrial Fibrillation, $\mathbf{n}(\%)$ & $387(47.5)$ & $347(41.8)$ & $415(46.8)$ & 0.038 \\
\hline Diabetes mellitus, $\mathrm{n}(\%)$ & $216(26.5)$ & $280(34.3)$ & $323(36.5)$ & $<0.001$ \\
\hline COPD, n (\%) & $155(19.0)$ & $114(14.0)$ & $167(18.8)$ & 0.009 \\
\hline Stroke, $\mathrm{n}(\%)$ & $84(10.3)$ & $67(8.2)$ & $82(9.3)$ & 0.340 \\
\hline PAD, n (\%) & $81(10.0)$ & $78(9.6)$ & $114(12.9)$ & 0.055 \\
\hline Device therapy, $\mathrm{n}(\%)$ & $166(20.4)$ & $173(21.2)$ & $279(31.5)$ & $<0.001$ \\
\hline $\mathrm{PCl}$ or $\mathrm{CABG}, \mathrm{n}(\%)$ & $259(31.8)$ & $258(31.6)$ & $325(36.7)$ & 0.042 \\
\hline Loop diuretic, $n(\%)$ & $810(99.5)$ & $816(100)$ & $878(99.1)$ & 0.026 \\
\hline ACEi/ARB, n (\%) & $597(73.3)$ & $640(78.4)$ & $583(65.8)$ & $<0.001$ \\
\hline$\geq 50 \%$ dose, $n(\%) *$ & $389(60.0)$ & $422(58.7)$ & $359(46.5)$ & 0.001 \\
\hline Beta-blocker, n (\%) & $659(81.0)$ & $714(87.5)$ & $720(81.3)$ & $<0.001$ \\
\hline$\geq 50 \%$ dose, $n(\%) *$ & $302(46.6)$ & $234(32.5)$ & $241(31.2)$ & $<0.001$ \\
\hline MRA, n (\%) & $347(42.6)$ & $543(66.5)$ & $449(50.7)$ & $<0.001$ \\
\hline Digoxin, $\mathrm{n}(\%)$ & $170(20.9)$ & $192(23.5)$ & $129(14.6)$ & $<0.001$ \\
\hline All-cause mortality, n (\%) & $238(29.2)$ & $197(24.1)$ & $222(25.1)$ & 0.043 \\
\hline During up-titration period $n(\%)$ & $67(8.2)$ & $43(5.3)$ & $41(4.6)$ & 0.004 \\
\hline HF hospitalization & $221(27.1)$ & $171(21.0)$ & $217(24.5)$ & 0.014 \\
\hline
\end{tabular}

Legend: ACEi angiotensin converting enzyme inhibitors; ARB angiotensin receptor blocker; BMI body mass index; CABG coronary artery bypass grafting; COPD chronic obstructive pulmonary disease; eGFR estimated glomerular filtration rate; HF heart failure; HR heart $r$ ate; JVP jugular venous pressure; LVEF left ventricular ejection fraction; MRA mineralocorticoid receptor antagonist; Nt -proBNP N-terminal pro brain natriuretic peptide; NYHA New York Heart Association; PAD peripheral artery disease; PCl percutaneous coronary intervention; SBP systolic blood pressure. 
Table 2 - Baseline characteristics of the BIOSTAT-CHF population by individual country

\begin{tabular}{|c|c|c|c|c|c|c|c|c|c|c|c|c|}
\hline & Netherlands & France & Gemany & Serbia & Slovenia & Greece & Italy & Norway & Sweden & Poland & UK & $\begin{array}{l}\text { P Value } \\
\text { P }\end{array}$ \\
\hline Number & $407(16.2)$ & $263(10.5)$ & 90 (3.6) & 385 (15.3) & $45(1.8)$ & $304(12.1)$ & $319(12.7)$ & $109(4.3)$ & $102(4.1)$ & $296(11.8)$ & $196(7.8)$ & \\
\hline Age, y & $71.1 \pm 11.6$ & $72.4 \pm 12.0$ & $66.5 \pm 10.1$ & $65.2 \pm 9.9$ & $74.6 \pm 7.2$ & $66.1 \pm 12.2$ & $67.4 \pm 12.9$ & $69.5 \pm 13.2$ & $71.1 \pm 12.7$ & $65.8 \pm 11.7$ & $70.2 \pm 11.7$ & $<0.001$ \\
\hline Male sex, $\mathrm{n}(\%)$ & $257(63.1)$ & $161(61.2)$ & $74(82.2)$ & $307(79.7)$ & $28(62,2)$ & $250(82.2)$ & $263(82,4)$ & $73(67.0)$ & $73(71.6)$ & $215(72.6)$ & $145(74.0)$ & $<0.001$ \\
\hline \multicolumn{13}{|l|}{ Race, $n(\%)$} \\
\hline White Caucasian & $\begin{array}{l}401(98.5) \\
6(151)\end{array}$ & $262(99.6)$ & $\begin{array}{l}89(98.9) \\
1(1.1)\end{array}$ & $\begin{array}{l}383(99.5) \\
2(155)\end{array}$ & $45(100.0)$ & $298(98.0)$ & $\begin{array}{l}314(98.4) \\
5(16)\end{array}$ & $\begin{array}{ll}106(97.2) \\
3(29 .)\end{array}$ & $102(100.0)$ & $296(100.0)$ & $\begin{array}{l}193(98.5) \\
\end{array}$ & $<0.001$ \\
\hline Other & $6(1.5)$ & $1(0.4)$ & $1(1.1)$ & $2(0.5)$ & & $6(2.0)$ & $5(1.6)$ & $3(2.8)$ & & & $3(1.5)$ & \\
\hline $\mathrm{BM}, \mathrm{Kg} / \mathrm{m} 2$ & $27.4 \pm 5.3$ & $27.5 \pm 6.4$ & $29.6 \pm 5.7$ & $27.8 \pm 4.7$ & $29.4 \pm 5.3$ & $28.2 \pm 5.2$ & $27.2 \pm 4.6$ & $26.2 \pm 5.0$ & $27.4 \pm 5.4$ & $28.5 \pm 5.3$ & $29.3 \pm 7.5$ & $<0.001$ \\
\hline $\mathrm{HR}$, bpm & $92.1 \pm 24.4$ & $81.7 \pm 20.2$ & $79.3 \pm 23.3$ & $77.1 \pm 16.9$ & $76.1 \pm 18.3$ & $78.3 \pm 17.6$ & $78.2 \pm 17.4$ & $88.5 \pm 27.3$ & $76.0 \pm 17.8$ & $83.3 \pm 20.9$ & $86.6 \pm 24.9$ & $<0.001$ \\
\hline SBP, mmHg & $128.2 \pm 26.1$ & $122.2 \pm 20.3$ & $119.7 \pm 17.9$ & $129.2 \pm 19.3$ & $131.7 \pm 19.4$ & $124.8 \pm 21.8$ & $121.0 \pm 19.9$ & $124.4 \pm 24.3$ & $126.4 \pm 22.8$ & $124.0 \pm 20.2$ & $118.9 \pm 22.2$ & $<0.001$ \\
\hline Pulmonay rales, $\mathrm{n}(\%)$ & $252(63.5)$ & $146(55.5)$ & $36(40.9)$ & $141(36.6)$ & $21(46.7)$ & $159(54.3)$ & $188(59.3)$ & $50(51.5)$ & $39(39.4)$ & $166(56.8)$ & $93(55.0)$ & $<0.001$ \\
\hline Peripheral edema, $\mathrm{n}(\%)$ & $233(62.6)$ & $146(85.9)$ & $72(92.3)$ & $142(39.4)$ & $22(51.2)$ & $123(57.5)$ & $117(43.2)$ & $41(64.1)$ & $62(79.5)$ & $179(66.1)$ & $119(66.9)$ & $<0.001$ \\
\hline Elevated $N \mathrm{P}, \mathrm{n}(\%)$ & $120(37.2)$ & $67(52.8)$ & $13(17.8)$ & $47(14.2)$ & $8(21.6)$ & $60(37.3)$ & $50(21.5)$ & $8(17.8)$ & $35(44.9)$ & $60(33.0)$ & $86(52.4)$ & $<0.001$ \\
\hline NYHA class III/IV, $n$ (\%) & $263(69.8)$ & $139(54.1)$ & $71(78.9)$ & $172(44.7)$ & $23(51.1)$ & $186(61.6)$ & $199(63.8)$ & $63(62.4)$ & $72(72.0)$ & $226(76.4)$ & $108(59.7)$ & $<0.001$ \\
\hline Orthopnea, n (\%) & $206(50.7)$ & $77(29.4)$ & $36(40.4)$ & $56(14.5)$ & $3(6.7)$ & $132(43.4)$ & $62(19.4)$ & $43(39.8)$ & $20(19.6)$ & $143(48.3)$ & $101(51.8)$ & $<0.001$ \\
\hline LVEF, \% & $32.3 \pm 12.9$ & $34.4 \pm 11.6$ & $28.9 \pm 9.4$ & $28.2 \pm 8.5$ & $46.1 \pm 16.3$ & $29.1 \pm 6.7$ & $29.7 \pm 8.8$ & $29.8 \pm 10.4$ & $30.2 \pm 8.5$ & $32.2 \pm 10.7$ & $32.8 \pm 12.2$ & $<0.001$ \\
\hline \multicolumn{13}{|l|}{ Primary HF etiology, $\mathrm{n}(\%)$} \\
\hline Ischemic & $161(39.6)$ & $103(39.2)$ & $50(55.6)$ & $186(48.3)$ & $19(42.2)$ & $151(49.7)$ & $151(47.3)$ & $37(33.9)$ & $36(35.3)$ & $126(42.6)$ & $83(42.3)$ & $<0.001$ \\
\hline Hypertensive & $40(9.8)$ & $\begin{array}{l}36(13.7) \\
36\end{array}$ & $\begin{array}{l}7(7.8) \\
\end{array}$ & $35(9.1)$ & $19(42.2)$ & $35(11.5)$ & $15(4.7)$ & $9(8.3)$ & $20(19.6)$ & $28(9.5)$ & $10(5.1)$ & \\
\hline Valvular & $51(12.5)$ & $25(9.5)$ & $7(7.8)$ & $24(6.2)$ & $3(6.7)$ & $16(5.3)$ & $14(4.4)$ & $7(6.4)$ & $4(3.9)$ & $29(9.8)$ & $10(5.1)$ & \\
\hline Other/miscellaneous & $155(38.1)$ & $99(37.6)$ & $26(28.9)$ & $140(36.4)$ & $4(8.9)$ & $102(33.6)$ & $139(43.6)$ & $56(51.4)$ & $42(41.2)$ & $113(38.2)$ & $93(47.4)$ & \\
\hline Hemoglobin, $\mathrm{g} / \mathrm{dL}$ & $13.1 \pm 2.1$ & $13.0 \pm 1.9$ & $13.2 \pm 1.8$ & $13.5 \pm 1.8$ & $13.1 \pm 1.8$ & $13.1 \pm 1.8$ & $13.0 \pm 1.8$ & $13.1 \pm 2.1$ & $13.4 \pm 1.6$ & $13.7 \pm 1.8$ & $12.7 \pm 1.9$ & $<0.001$ \\
\hline $\mathrm{eGFR}, \mathrm{ml} / \mathrm{min} / 1.73 \mathrm{~m}^{2}$ & $59.4 \pm 22.7$ & $56.9 \pm 23.0$ & $63.7 \pm 22.4$ & $66.0 \pm 23.0$ & $55.0 \pm 17.5$ & $65.0 \pm 22.4$ & $63.9 \pm 24.6$ & $65.1 \pm 24.1$ & $57.3 v 21.5$ & $69.1 \pm 21.7$ & $55.2 \pm 23.0$ & $<0.001$ \\
\hline Sodium, $\mathrm{mmol} / \mathrm{L}$ & $139.3 \pm 3.8$ & $138.7 \pm 3.5$ & $139.0 \pm 4.3$ & $140.4 \pm 3.3$ & $140.4 \pm 3.3$ & $138.1 \pm 4.9$ & $139.4 \pm 3.7$ & $139.9 \pm 3.6$ & $140.2 \pm 3.4$ & $139.2 \pm 4.1$ & $136.8 \pm 4.2$ & $<0.001$ \\
\hline Potassium, $\mathrm{mmol} / \mathrm{L}$ & $4.1 \pm 0.5$ & $4.1 \pm 0.5$ & $4.2 \pm 0.5$ & $4.5 \pm 0.5$ & $4.8 \pm 0.8$ & $4.4 \pm 0.6$ & $4.2 \pm 0.6$ & $4.3 \pm 0.5$ & $4.2 \pm 0.4$ & $4.3 \pm 0.6$ & $4.3 \pm 0.6$ & $<0.001$ \\
\hline LogNT-pro BNP, ng/L & $3.51 \pm 1.36$ & $3.22 \pm 1.35$ & $3.14 \pm 1.35$ & $2.50 \pm 1.37$ & $2.94 \pm 1.07$ & $2.74 \pm 1.38$ & $2.72 \pm 1.29$ & $2.87 \pm 1.09$ & $3.33 \pm 1.29$ & $3.13 \pm 1.40$ & $3.51 \pm 1.40$ & $<0.001$ \\
\hline Hypentension, $\mathrm{n}(\%)$ & $218(53.6)$ & $164(62.4)$ & $80(88.9)$ & $294(76.4)$ & $43(95.6)$ & $179(58.9)$ & $201(63.0)$ & $40(36.7)$ & $53(52.0)$ & $198(66.9)$ & $99(50.5)$ & $<0.001$ \\
\hline Atrial Fibrillation, $\mathrm{n}(\%)$ & $\begin{array}{l}10(30.0) \\
191(46.9) \\
\end{array}$ & $\frac{104(20.46)}{148(56.3)}$ & $\begin{array}{l}49(54.4) \\
49(10.9)\end{array}$ & $\frac{154 \mid 0.47)}{129(33.5)}$ & $\begin{array}{l}450(66.7) \\
30.7)\end{array}$ & $141(46.4)$ & $\begin{array}{l}201(30.0) \\
126(39.5)\end{array}$ & $\begin{array}{l}40(30.1) \\
51(46.8)\end{array}$ & $\frac{53(151.0)}{52(51.0)}$ & $\frac{190(44.9)}{133(13)}$ & $\begin{array}{l}93(47.4) \\
93.4)\end{array}$ & $<0.001$ \\
\hline Diabetes mellitus, $n$ (\%) & $113(27.8)$ & $91(34.6)$ & $50(55.6)$ & $110(28.6)$ & $16(35.6)$ & $122(40.1)$ & $110(34.5)$ & $20(18.3)$ & $22(21.6)$ & $104(35.1)$ & $61(31.1)$ & $<0.001$ \\
\hline COPD, n (\%) & $94(23.1)$ & $50(19.0)$ & $21(23.3)$ & $49(12.7)$ & $4(8.9)$ & $51(16.8)$ & $66(20.7)$ & $16(14.7)$ & $11(10.8)$ & $40(13.5)$ & $34(17.3)$ & 0.001 \\
\hline Stroke, $n(\%)$ & $45(11.1)$ & $33(12.5)$ & $8(8.9)$ & $24(6.2)$ & $4(8.9)$ & $24(7.9)$ & $25(7.8)$ & $4(3.7)$ & $13(12.7)$ & $31(10.5)$ & $22(11.2)$ & 0.063 \\
\hline PAD, n (\%) & $51(12.5)$ & $40(15.2)$ & $22(24.4)$ & $21(5.5)$ & $3(6.7)$ & $32(10.5)$ & $42(13.2)$ & $1(0.9)$ & $8(7.8)$ & $32(10.8)$ & $21(10.7)$ & $<0.001$ \\
\hline Device therapy, $\mathrm{n}(\%)$ & $79(19.7)$ & $69(26.2)$ & $52(57.8)$ & $47(12.2)$ & $2(4.4)$ & $67(22.0)$ & $143(44.8)$ & $16(14.7)$ & $28(27.5)$ & $72(24.3)$ & $43(21.9)$ & $<0.001$ \\
\hline PCl orCABG, $n(\%)$ & $128(31.4)$ & $81(30.8)$ & $58(64.4)$ & $95(24.7)$ & $17(37.8)$ & $127(41.8)$ & $117(36.7)$ & $40(36.7)$ & $27(26.5)$ & $88(29.7)$ & $64(32.7)$ & $<0.001$ \\
\hline Loop diuretic, $n(\%)$ & $406(99.8)$ & $260(98.9)$ & $90(100)$ & $385(100)$ & $45(100)$ & $301(99.0)$ & $317(99.4)$ & 108 (99.1) & $102(100)$ & $296(100)$ & $194(99.0)$ & 0.375 \\
\hline ACE & $270(66.3)$ & $152(57.8)$ & $81(90.0)$ & $321(83.4)$ & $16(35.6)$ & $207(68.1)$ & $224(70.2)$ & $85(78.0)$ & $79(77.5)$ & $222(75.0)$ & $163(83.2)$ & $<0.001$ \\
\hline $250 \%$ dose, $n(\%)^{*}$ & $212(52.1)$ & $130(49.4)$ & $60(66.7)$ & $232(60.3)$ & $29(64.4)$ & $128(42.1)$ & $135(42.3)$ & $67(61.5)$ & $74(72.5)$ & $147(49.7)$ & $98(50.0)$ & $<0.001$ \\
\hline Beta-blocker, $\mathrm{n}(\%)$ & $317(77.9)$ & $194(73.8)$ & $88(97.8)$ & $335(87.0)$ & $29(66.4)$ & $246(80.9)$ & $280(87.8)$ & $81(74.3)$ & $87(85.3)$ & $262(88.5)$ & $174(88.8)$ & $<0.001$ \\
\hline$\geq 50 \%$ dose, $n(\%)^{*}$ & $215(52.8)$ & $109(41.4)$ & $33(36.7)$ & $112(29.1)$ & $26(57.8)$ & $34(11.2)$ & $121(37.9)$ & $52(47.7)$ & $68(66.7)$ & $94(31.8)$ & $38(19.4)$ & $<0.001$ \\
\hline MRA, $n(\%)$ & $\frac{151(3.6)}{157(38.6)}$ & $\frac{105(14.4)}{81(30.8)}$ & $\begin{array}{l}35(130.4) \\
584)\end{array}$ & $284(73.8)$ & $26(57.8)$ & $\frac{54(11.27}{185(60.9)}$ & $\frac{11(1.3)}{183(57.4)}$ & $\frac{32(41.0)}{33(30.3)}$ & $\frac{0.00 .11}{33(32.4)}$ & $175(59.1)$ & $\frac{30(17.4)}{124(63.3)}$ & $<0.001$ \\
\hline Digoxin, $\mathrm{n}(\%)$ & $73(17.9)$ & $\frac{01(30.0)}{23(8.7)}$ & $\frac{50(104.4)}{20(22.2)}$ & $\frac{204(5.0)}{88(22.9)}$ & $\frac{2001}{0}$ & $\frac{105(14.5)}{44(14)}$ & $\frac{105(3.4)}{62(19.4)}$ & $\frac{19(17.4)}{19(17)}$ & $\frac{53(10.4)}{11(10.8)}$ & $\frac{15(28.1)}{84(28)}$ & $\frac{124(35.3)}{67(34.2)}$ & $<0.001$ \\
\hline$A C M, n(\%)$ & $129(31.7)$ & $78(29.7)$ & $27(30.0)$ & $72(18.7)$ & $18(40.0)$ & $78(25.7)$ & $66(20.7)$ & $27(24.8)$ & $26(25.5)$ & $80(27.0)$ & $56(28.6)$ & $<0.001$ \\
\hline Duing up-titation period & $42(10.3 \%)$ & $19(7.2)$ & $3(3.3)$ & $18(4.7)$ & $5(11.1)$ & $13(4.3)$ & $9(2.8)$ & $8(7.3)$ & 0 & $17(5.7)$ & $17(8.7)$ & $<0.001$ \\
\hline & $109(26.8)$ & $83(31.6)$ & $22(24.4)$ & $50(13.0)$ & $18(40.0)$ & $56(18.4)$ & $78(24.5)$ & $30(27.5)$ & $31(30.4)$ & $81(27.4)$ & $51(26.0)$ & $<0.001$ \\
\hline $\mathrm{ACM}+\mathrm{HHF}$ & 186 (45.7) & $124(47.1)$ & $42(46.7)$ & $108(28.1)$ & $27(60.0)$ & 106 (34.9) & $121(37.9)$ & $47(43.1)$ & $45(44.1)$ & $128(43.2)$ & $83(42.3)$ & $<0.001$ \\
\hline
\end{tabular}


Table 2. Clinical Outcomes by geographic area

\begin{tabular}{|c|c|c|c|c|c|c|c|c|c|}
\hline & $\begin{array}{c}\text { Northern } \\
\text { Area }\end{array}$ & Central Area & $\begin{array}{c}\text { Mediterranean } \\
\text { Area }\end{array}$ & \multicolumn{2}{|c|}{ Mediterranean vs Northern Area } & \multicolumn{2}{|c|}{ Mediterranean vs Central Area } & \multicolumn{2}{|c|}{ Central vs Northern Area } \\
\hline N. patients & 814 & 816 & 886 & Hazard Rat & io $(95 \% \mathrm{Cl})$ & Hazard Rat & io $(95 \% \mathrm{Cl})$ & Hazard Ra & o (95\% Cl) \\
\hline Outcome & \multicolumn{3}{|c|}{ Event rates per 100 person-years } & Unadjusted & \begin{tabular}{|l} 
Adjusted* \\
\end{tabular} & Unadjusted & \begin{tabular}{|l|} 
Adjusted* \\
\end{tabular} & Unadjusted & Adjusted* \\
\hline All-cause mortality & 16.6 & 15.0 & 14.8 & $0.89(0.74-1.07)$ & $0.96(0.77-1.19)$ & $0.99(0.82-1.20)$ & $0.77(0.63-0.95)$ & $0.89(0.74-1.08)$ & $1.23(0.98-1.55)$ \\
\hline HF hospitalization & 18.5 & 17.0 & 14.7 & $0.89(0.74-1.08)$ & $0.91(0.73-1.14)$ & $1.19(0.97-1.45)$ & $0.97(0.79-1.19)$ & $0.75(0.62-0.92)$ & $0.93(0.74-1.19)$ \\
\hline $\begin{array}{l}\text { All-cause mortality } \\
+ \text { HF hospitalization }\end{array}$ & 30.3 & 27.6 & 26.2 & $0.89(0.77-1.04)$ & $0.93(0.77-1.11)$ & $1.07(0.92-1.25)$ & $0.86(0.73-1.01)$ & $0.83(0.71-0.97)$ & $1.07(0.89-1.29)$ \\
\hline
\end{tabular}

*adjusted on age, gender, heart rate, pulmonary congestion, peripheral edema, elevated jugular venous pressure, NYHA class, orthopnea, left ventricular ejection fraction, primary heart failure cause, potassium, NtproBNP, hypertension, atrial fibrillation, diabetes, angiotensin converting enzyme inhibitor use and mineralocorticoid receptor antagonist use (i.e. the baseline differences observed from table 1 )

Legend: $\mathrm{Cl}$ confidence interval; $\mathrm{HF}$ heart failure. 


\section{Figure legend}

Figure 1. Individual country contribute to enrollment in the BIOSTAT-CHF study.

\section{Figure 1 Individual country contribute in BIOSTAT-CHF}

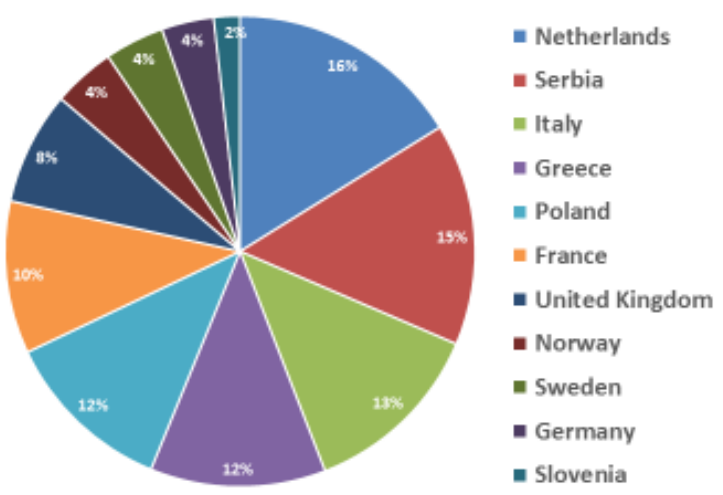

Figure 2. Treatment according to geographic area

Figure 2. Treatment according to geographic area

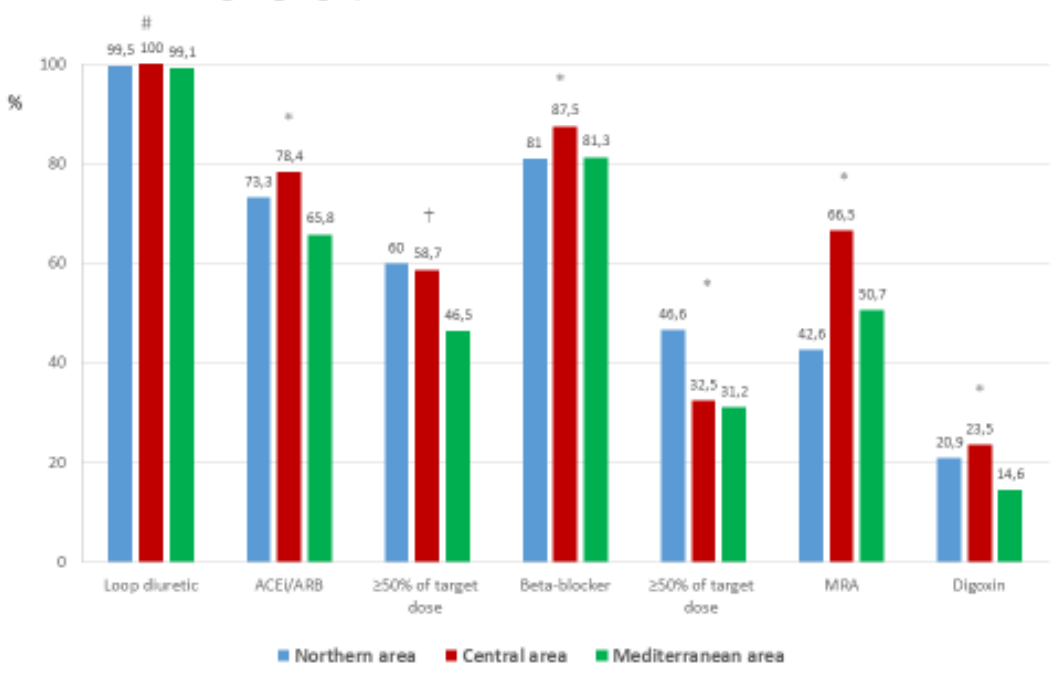


Figure $\mathbf{3}(\mathbf{a}, \mathbf{b}, \mathbf{c})$. Kaplan-Meier plots according to European region. (a) All-cause mortality and HF hospitalization; (b) all-cause mortality; (c) HF hospitalization

\section{Figure 3a}

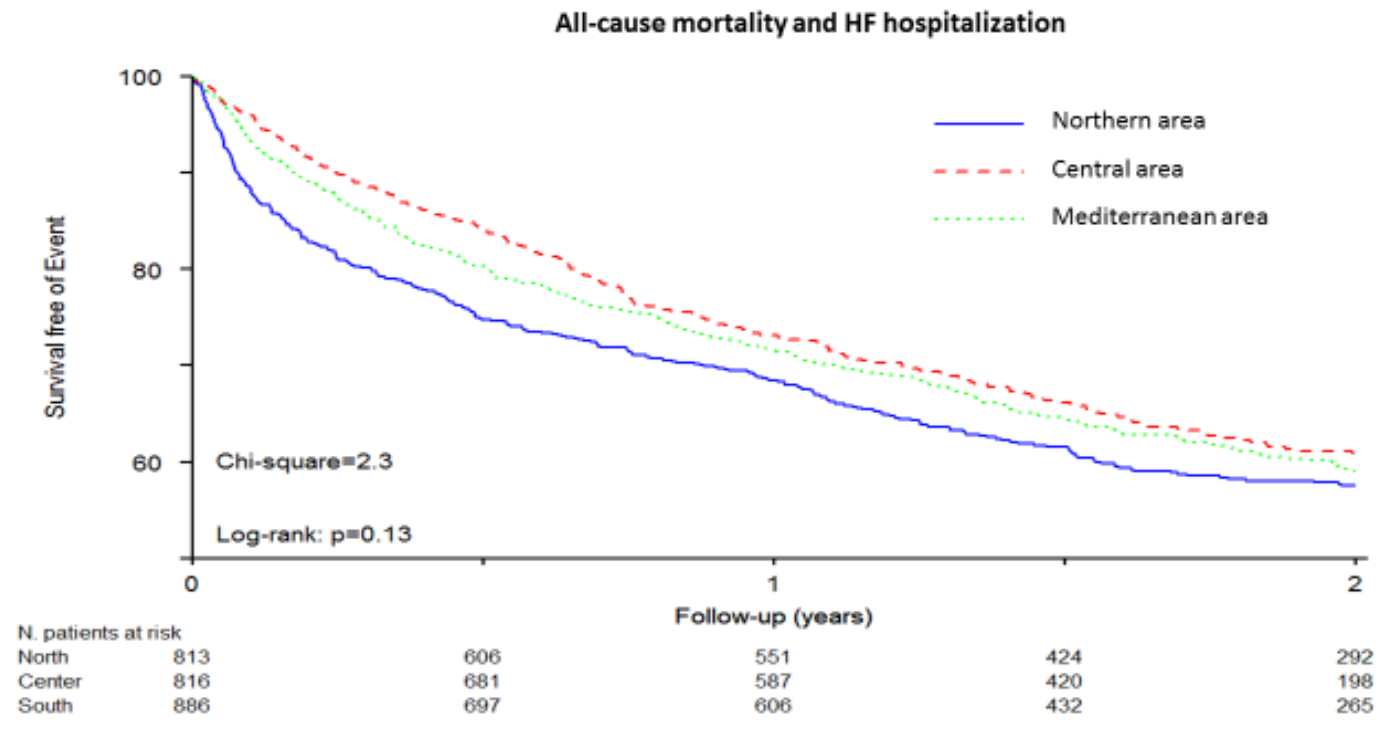

Figure 3b

All-cause mortality

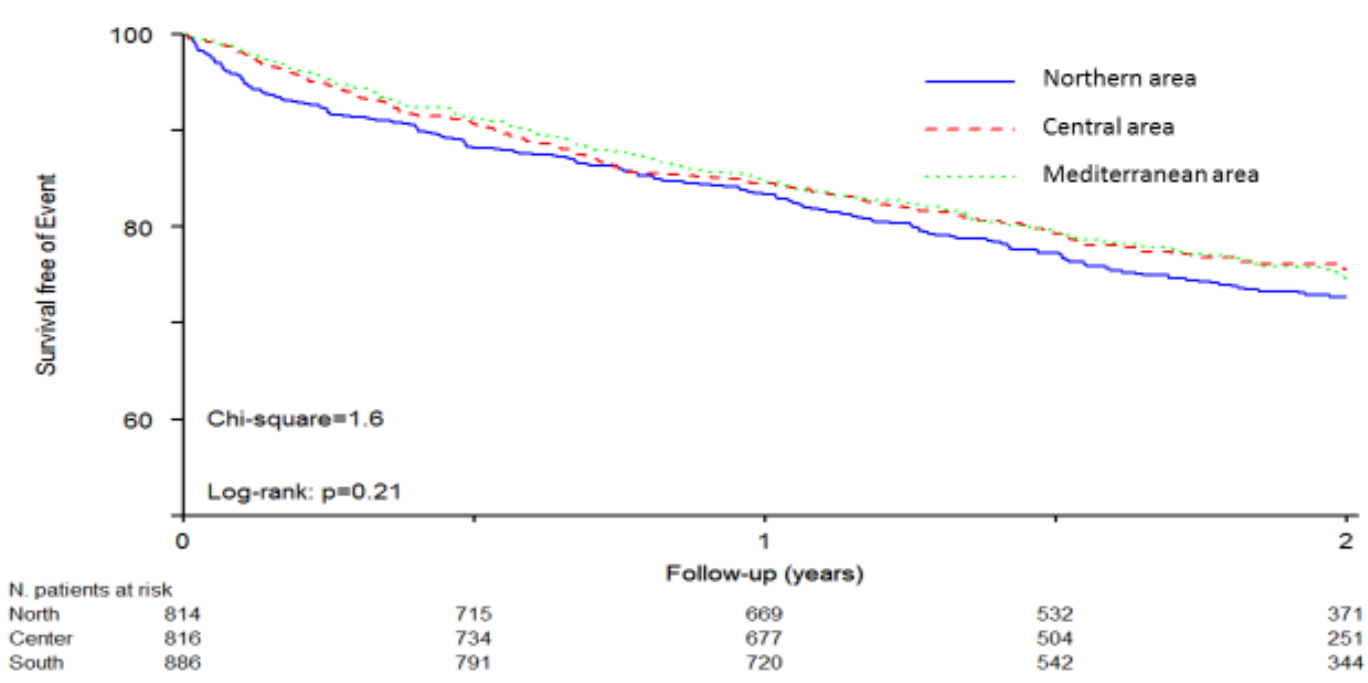


Figure 3c

HF hospitalization

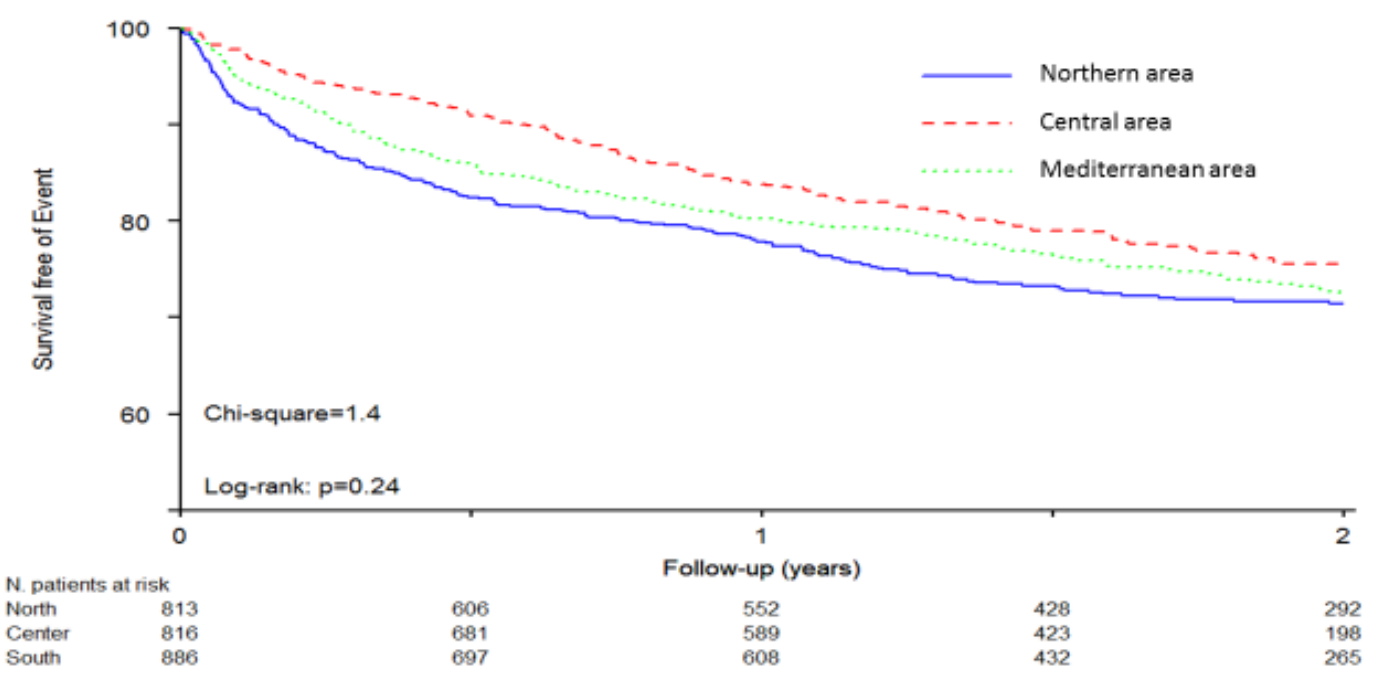


Figure 4: country-by-country distribution of signs of congestion

Figure 4: country-by-country distribution of signs of congestion
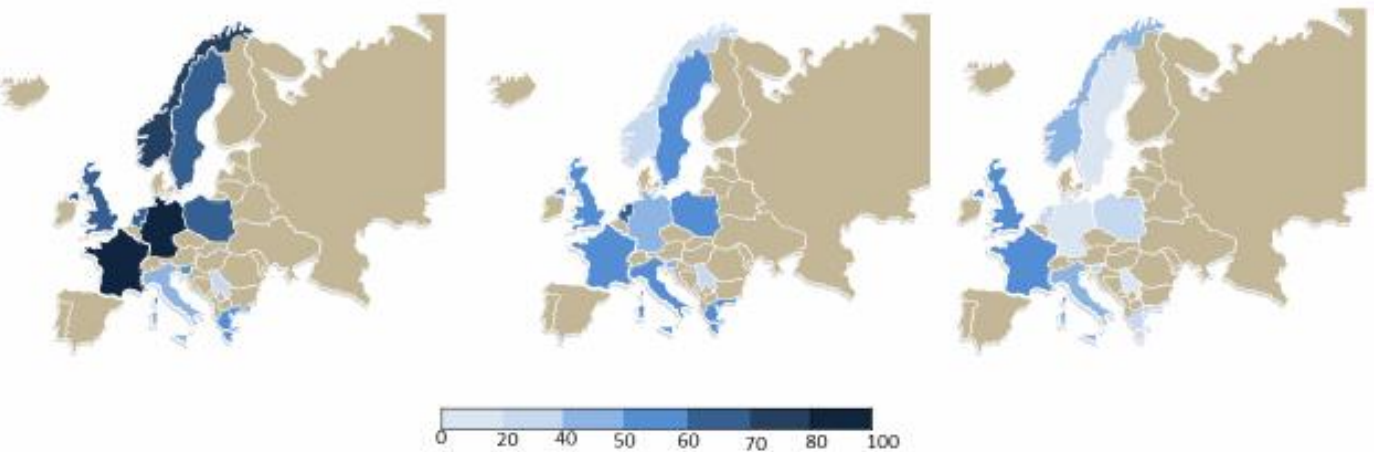

Figure 5: country-by-country distribution of outcomes

Figure 5: country-by-country distribution of outcomes

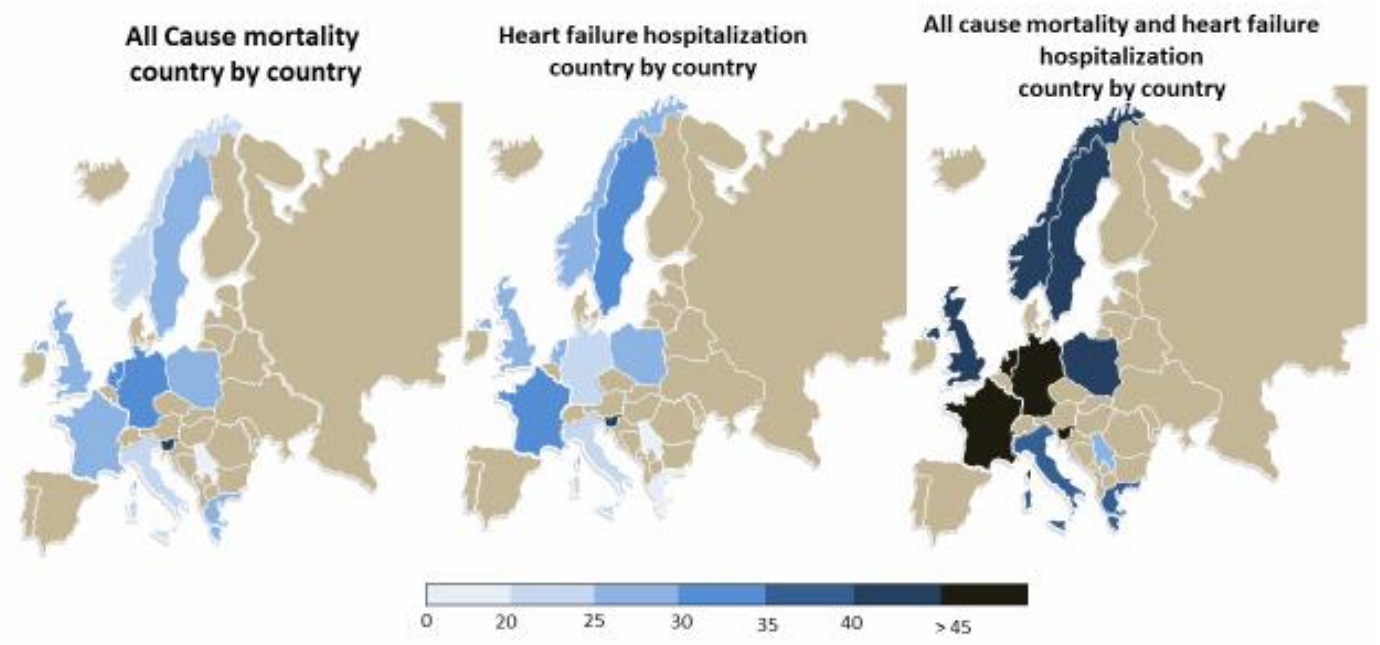




\title{
REFERENCES
}

\begin{abstract}
${ }^{1}$ Poni kowski P, Voors AA, Anker SD, Bueno H, Clel and JG, Coats AJ, Falk V, Gonzalez-Juanatey JR, Harjola VP, Jankowska EA, Jessup M, Linde C, Nihoyannopoul os P, Parissis JT, Pieske B, Riley JP, Rosano GM, Ruilope LM, Ruschitzka F, Rutten FH, van der Meer P, Authors/Task Force M and Document R. 2016 ESC Guidelines for the diagnosis and treatment of acute and chronic heart failure: The Task Force for the diagnosis and treatment of acute and chronic heart failure of the European Society of Cardiology (ESC). Developed with the special contribution of the Heart Failure Association (HFA) of the ESC. European journal of heart failure. 2016;18:891-975.
\end{abstract}

${ }^{2}$ Schmidt M, Ulrichsen SP, Pedersen L, Botker HE and Sorensen HT. Thirty-year trends in heart failure hospitalization and mortality rates and the prognostic impact of co-morbidity: a Danish nationwide cohort study. European journal of heart failure. 2016;18:490-9.

${ }^{3}$ Omersa D, Farkas J, Erzen I and Lainscak M. National trends in heart failure hospital ization rates in Slovenia 2004-2012. European journal of heart failure. 2016;18:1321-1328.

${ }^{4}$ Metra M and Teerlink JR. Heart failure. Lancet. 2017.

${ }^{5}$ Massie BM, Cleland JG, Armstrong PW, Horowitz JD, Packer M, Poole-Wilson PA and Ryden L. Regional differences in the characteristics and treatment of patients participating in an international heart failure trial. The Ass essment of Treatment with Lisinopril and Survival (ATLAS) Trial Investigators. Journal of cardiac failure. 1998;4:3-8.

${ }^{6}$ Blair JE, Zannad F, Konstam MA, Cook T, Traver B, Burnett JC, Jr., Grinfeld L, Krasa H, Maggioni AP, Orlandi C, Swedberg K, Udelson JE, Zimmer C, Gheorghiade M and Investigators E. Continental differences in clinical characteristics, management, and outcomes in patients hospitalized with worsening heart failure results from the EVEREST (Efficacy of Vasopressin Antagonism in Heart Failure: Outcome Study with Tolvaptan) program. Journal of the American College of Cardiology. 2008;52:1640-8.

${ }^{7}$ O'Connor CM, Fiuzat M, Swedberg K, Caron M, Koch B, Carson PE, Gattis-Stough W, Davis GW and Bristow MR. Influence of gl obal region on outcomes in heart failure beta -blocker trials. Journal of the American College of Cardiology. 2011;58:915-22.

${ }^{8}$ Metra M, Ponikowski P, Cotter G, Davison BA, Felker GM, Filippatos G, Greenberg BH, Hua TA, Severin T, Unemori E, Voors AA and TeerlinkJR. Effects of serelaxin in subgroups of patients with acute heart failure: results from RELAX-AHF. European heart journal. 2013;34:3128-36.

${ }^{9}$ Pfeffer MA, Claggett B, Assmann SF, Boineau R, Anand IS, Clausell N, Desai AS, Diaz R, Fleg JL, Gordeev I, Heitner JF, Lewis EF, O'Meara E, Rouleau JL, Probstfield JL, Shaburishvili T, Shah SJ, Sol omon SD, Sweitzer NK, McKinlay SM and Pitt B. Regional variation in patients and outcomes in the Treatment of Preserved Cardiac Function Heart Failure With an Aldosterone Antagonist (TOPCAT) trial. Circulation. 2015;131:34-42.

${ }^{10}$ Metra M, Mentz RJ, Hernandez AF, Heizer GM, Armstrong PW, Clausell N, Corbalan R, Cos tanzo MR, Dickstein K, Dunlap ME, Ezekowitz JA, Howlett JG, Komajda M, Krum H, Lombardi C, Fonarow 
GC, McMurray JJ, Nieminen MS, Swedberg K, Voors AA, Starling RC, Teerlink JR and O'Connor CM. Geographic Differences in Patients in a Global Acute Heart Failure Clinical Trial (from the ASCENDHF Trial). The American journal of cardiology. 2016;117:1771-8.

${ }^{11}$ Kristensen SL, Martinez F, Jhund PS, Arango JL, Belohlavek J, Boytsov S, Cabrera W, Gomez E, Hagege AA, Huang J, Kiatchoosakun S, Kim KS, Mendoza I, Senni M, Squire IB, Vinereanu D, Wong RC, Gong J, Lefkowitz MP, Ri zkala AR, Rouleau JL, Shi VC, Sol omon SD, Swedberg K, Zile MR, Packer $\mathrm{M}$ and McMurray JJ. Geographic variations in the PARADIGM-HF heart failure trial. European heart journal. 2016;37:3167-3174.

${ }^{12}$ Dokainish H, Teo K, Zhu J, Roy A, Al Habib KF, ElSayed A, Palileo-Villaneuva L, Lopez-Jaramillo P, Karaye K, Yus off K, Orlandini A, Sliwa K, Mondo C, Lanas F, Prabhakaran D, Badr A, Elmaghawry M, Damasceno A, Tibazarwa K, Belley-Cote E, Balasubramanian K, Islam S, Yacoub MH, Huffman MD, Harkness K, Grinvalds A, McKelvie R, Bangdiwala SI, Yusuf S and Investigators I-C. Gl obal mortality variations in patients with heart failure: results from the International Congestive Heart Failure (INTER-CHF) prospective cohort study. Lancet Glob Health. 2017;5:e665-e672.

${ }^{13}$ Dokainish H, Teo K, Zhu J, Roy A, Al Habib KF, ElSayed A, Palileo-Villaneuva L, Lopez-Jaramillo P, Karaye K, Yus off K, Orlandini A, Sliwa K, Mondo C, Lanas F, Prabhakaran D, Badr A, El maghawry M, Damasceno A, Tibazarwa K, Belley-Cote E, Balasubramanian K, Islam S, Yacoub MH, Huffman MD, Harkness K, Grinvalds A, McKelvie R, Bangdiwala SI, Yusuf S and Investigators I-C. Gl obal mortality variations in patients with heart failure: results from the International Congestive Heart Failure (INTER-CHF) prospective cohort study. Lancet Glob Health. 2017;5:e665-e672.

${ }^{14}$ van Veldhuisen DJ, Charlesworth A, Crijns HJ, Lie KI and Hampton JR. Differences in drug treatment of chronic heart failure between European countries. European heart journal. 1999;20:666-72.

${ }^{15}$ Maggioni AP, Dahlstrom U, Filippatos G, Chioncel O, Lei ro MC, Drozdz J, Fruhwald F, Gullestad L, Logeart D, Fabbri G, Urso R, Metra M, Parissis J, Persson H, Ponikowski P, Rauchhaus M, Voors AA, Nielsen OW, Zannad F, Tavazzi L and Heart Failure Association of the European Society of C. EURO bservational Res earch Programme: regional differences and 1-year follow-up results of the Heart Failure Pil ot Survey (ESC-HF Pilot). European journal of heart failure. 2013;15:808-17.

${ }^{16}$ Crespo-Leiro MG, Anker SD, Maggioni AP, Coats AJ, Filippatos G, Ruschitzka F, Ferrari R, Piepoli MF, Del gado Jimenez JF, Metra M, Fonseca C, Hradec J, Ami r O, Logeart D, Dahlstrom U, Merkely B, Drozdz J, Goncalvesova E, Hassanein M, Chioncel O, Lainscak M, Seferovic PM, Tousoulis D, Kavoliuniene A, Fruhwald F, Fazlibegovic E, Temizhan A, Gatzov P, Erglis A, Laroche C, Mebazaa A and Heart Failure Association of the European Society of C. European Soci ety of Cardiology Heart Failure Long-Term Regi stry (ESC-HF-LT): 1-year follow-up outcomes and differences across regions. European journal of heart failure. 2016;18:613-25.

${ }^{17}$ Chi oncel O, Mebazaa A, Harjola VP, Coats A, Piepoli MF, Crespo-Leiro MG, La roche C, Seferovic PM, Anker SD, Ferrari R, Ruschitzka F, Lopez-Fernandez S, Miani D, Filippatos G, Maggioni AP and Investigators ESCHFL-TR. Clinical phenotypes and outcome of patients hospitalized for acute heart failure: the ESC Heart Failure Long-Term Registry. European journal of heart failure. 2017. 
${ }^{18}$ Voors AA, Anker SD, Cleland JG, Dickstein K, Filippatos G, van der Harst P, Hillege HL, Lang CC, Ter Maaten JM, Ng L, Poni kowski P, Samani NJ, van Veldhuisen DJ, Zannad F, Zwinderman AH and Metra M. A systems BIOlogy Study to TAilored Treatment in Chronic Heart Failure: rationale, design, and baseline characteristics of BIOSTAT-CHF. European journal of heart failure. 2016;18:716-26.

${ }^{19}$ Dickstein K, Cohen-Solal A, Filippatos G, McMurray JJ, Ponikowski P, Poole-Wilson PA, Stromberg A, van Veldhuisen DJ, Atar D, Hoes AW, Keren A, Mebazaa A, Nieminen M, Priori SG, Swedberg K and Guidelines ESCCfP. ESC Guidelines for the diagnosis and treatment of acute and chronic heart failure 2008: the Task Force for the Diagnosis and Treatment of Acute and Chronic Heart Failure 2008 of the European Society of Cardiology. Devel oped in collaboration with the Heart Failure Association of the ESC (HFA) and endorsed by the European Society of Intensive Care Medicine (ESICM). European heart journal. 2008;29:2388-442.

${ }^{20}$ Assarsson E, Lundberg M, Holmquist G, Björkesten J, Thorsen SB, Ekman D, Eriksson A, Rennel Dickens E, Ohlsson S, Edfeldt G, Andersson AC, Lindstedt P, Stenvang J, Gullberg M, Fredriksson S. Homogenous 96-pl ex PEA immunoassay exhibiting high sensitivity, specificity, and excellent scalability. PLoS One. 2014 Apr 22;9(4):e95192.

${ }^{21}$ Voors AA, Ouwerkerk W, Zannad F, van Veldhuisen DJ, Samani NJ, Ponikowski P, Ng LL, Metra M, Ter Maaten JM, Lang CC, Hillege HL, van der Harst P, Filippatos G, Di ckstein K, Cleland JG, Anker SD and Zwinderman AH. Devel opment and validation of multivariable models to predict mortality and hospitalization in patients with heart failure. European journal of heart failure. 2017;19:627634.

${ }^{22}$ Ouwerkerk W, Voors AA, Anker SD, Cleland JG, Di ckstein K, Filippatos G, van der Harst P, Hillege HL, Lang CC, Ter Maaten JM, Ng LL, Ponikowski P, Samani NJ, van Veldhuisen DJ, Zannad F, Metra $\mathrm{M}$ and Zwinderman $\mathrm{AH}$. Determinants and clinical outcome of uptitration of ACE-inhibitors and beta-blockers in patients with heart failure: a prospective European study. European heart journal. 2017;38:1883-1890.

${ }^{23}$ Lund LH, Braunschweig F, Benson L, Stahlberg M, Dahlstrom U and Linde C. Association between demographic, organizational, clinical, and socio-economic characteristics and underutilization of cardiac resynchronization therapy: results from the Swedish Heart Failure Registry. European journal of heart failure. 2017;19:1270-1279.

${ }^{24}$ Guder G, Stork S, Gel brich G, Brenner S, Deubner N, Morbach C, Wallenborn J, Berliner D, Ertl G and Angermann CE. Nurse-coordinated collaborative di sease management improves the quality of guidel ine-recommended heart failure therapy, patient-reported outcomes, and left ventricular remodelling. European journal of heart failure. 2015;17:442-52.

${ }^{25}$ Devaux M. Income-related inequalities and inequities in heal th care services utilisation in 18 selected OECD countries. Eur J Health Econ. 2015;16:21-33.

${ }^{26}$ Yusuf S, Rangarajan S, Teo K, Islam S, Li W, Liu L, Bo J, Lou Q, Lu F, Liu T, Yu L, Zhang S, Mony P, Swaminathan S, Mohan V, Gupta R, Kumar R, Vijayakumar K, Lear S, Anand S, Wiel gosz A, Diaz R, Avezum A, Lopez-Jaramillo P, Lanas F, Yus off K, Ismail N, Iqbal R, Rahman O, Rosengren A, Yusufali 
A, Keli shadi R, Kruger A, Puoane T, Szuba A, Chifamba J, Oguz A, McQueen M, McKee M, Dagenais $G$ and Investigators P. Cardiovascular risk and events in 17 low-, middle-, and high-income countries. The New England journal of medicine. 2014;371:818-27.

${ }^{27}$ Maggi oni AP. Uncovering difference: a glimpse at patients with heart failure in low-income and middle-income countries. Lancet Gl ob Health. 2017 Jul;5(7):e634-e635.

${ }^{28}$ Dokainish H, Teo K, Zhu J, Roy A, Al-Habib K, El Sayed A, Palileo L, Jaramill o PL, Karaye K, Yus off K, Orlandini A, Sliwa K, Mondo C, Lanas F, Dorairaj P, Huffman M, Badr A, Elmaghawry M, Damasceno A, Belley-Cote E, Harkness K, Grinvalds A, McKelvie R, Yusuf S. Heart failure in low- and middle-income countries: background, rationale, and design of the INTERnational Congestive Heart Failure Study (INTER-CHF). Am Heart J. 2015 Oct;170(4):627-634. 